\title{
NDVI-BASED DOWNSCALING OF THE CREMAP ACTUAL EVAPOTRANSPIRATION MAPS
}

\author{
Péter Csáki, Kornél Czimber, Géza Király, Péter KaliCZ, \\ Katalin ZAGYVAI-KIss, Zoltán GRIBOvSZKI \\ University of Sopron, Institute of Geomatics and Civil Engineering \\ H-9400 Sopron, Bajcsy-Zsilinszky 4.
}

\begin{abstract}
The increasingly used remote sensing-based evapotranspiration estimation techniques provide information about the spatial and temporal variability of evapotranspiration on the field and regional scales. For Hungary, the most reliable evapotranspiration mapping model is the CREMAP (Calibration-Free Evapotranspiration Mapping), which uses MODIS surface temperature data. The CREMAP evapotranspiration with its $1000 \times 1000 \mathrm{~m}\left(1 \mathrm{~km}^{2}\right)$ resolution can be used for examinations with larger scales, for example the comparison of the water balance of forests with different land cover types (agricultural areas, artificial surfaces, etc.). However, the $1 \mathrm{~km}^{2}$ spatial resolution is too coarse to be used for smaller scales like precision forest management or agroforestry systems. Therefore, a vegetation index-based (MODIS NDVI) downscaling process of the CREMAP evapotranspiration was developed, to a resolution of $250 \times 250 \mathrm{~m}$ (6.25 hectares). The downscaling experiment was done for Hungary, for a drier (2003 May-October) and for a wetter (2005 MayOctober) period. The products were analyzed, according to forest stand types. The vegetation indexbased evapotranspiration downscaling process can be used for getting bydrological data for forest resource management, climate change impact studies on smaller scales or agroforestry system research.
\end{abstract}

Keywords: evapotranspiration, water balance, MODIS

\section{INTRODUCTION}

Through evapotranspiration (ET; which includes evaporation, transpiration and sublimation) more precipitation is disposed than through runoff. To increase the knowledge of the energy balance and the hydrological cycle of forestry and agriculture, it is essential to determine more accurately the amount of ET.

The conventional ET estimating techniques (eddy covariance, Bowen-ratio, lysimeter methods, catchment water balance equation, etc.) do not provide information about the spatial variability within a region of interest. The only possibility of estimating ET over areas with mixed landscape units is remote sensing, which allows to obtain information about spatial and temporal variability. Nowadays several remote sensing-based evapotranspiration estimation methods are available (Nouri et al., 2013, Zhang et al., 2016).

For Hungary, the most reliable evapotranspiration mapping model is the Complementary-Relationship-based Evapotranspiration MAPping (CREMAP, 
Szilágyi and Kovács, 2011). It is based on the complementary relationship (Bouchet, 1963) and the WREVAP model of Morton (1985) and it uses MODIS surface temperature data (linear transformation). It has a $1 \mathrm{~km}^{2}(1000 \times 1000 \mathrm{~m})$ spatial resolution, which can be used for examinations with larger scales, for example the comparison of the water balance of forests with different land cover types (agricultural areas, artificial surfaces, etc.). In Hungary, the units of forest management are the forest compartments (fairly homogeneous forest stands) which commonly have a relatively small area (approx. 5 ha). The CREMAP ET map (raster layer) and the Hungarian National Forestry Database (vector layer) for an example area are depicted in Figure 1. The $1 \mathrm{~km}^{2}$ spatial resolution is too coarse to be used for smaller scales, like precision forest management or agroforestry systems.

With higher resolution the ET maps could be more usable on scales of the forest stands. The aim of this study is the development of a vegetation-index based ET statistical downscaling method for Hungary. Employing the method, we compared the ET of different forest stand types during two vegetation periods.

\section{Figure 1}

\section{The CREMAP ET (raster layer) and the Hungarian National Forestry Database (vector layer) for an example area}

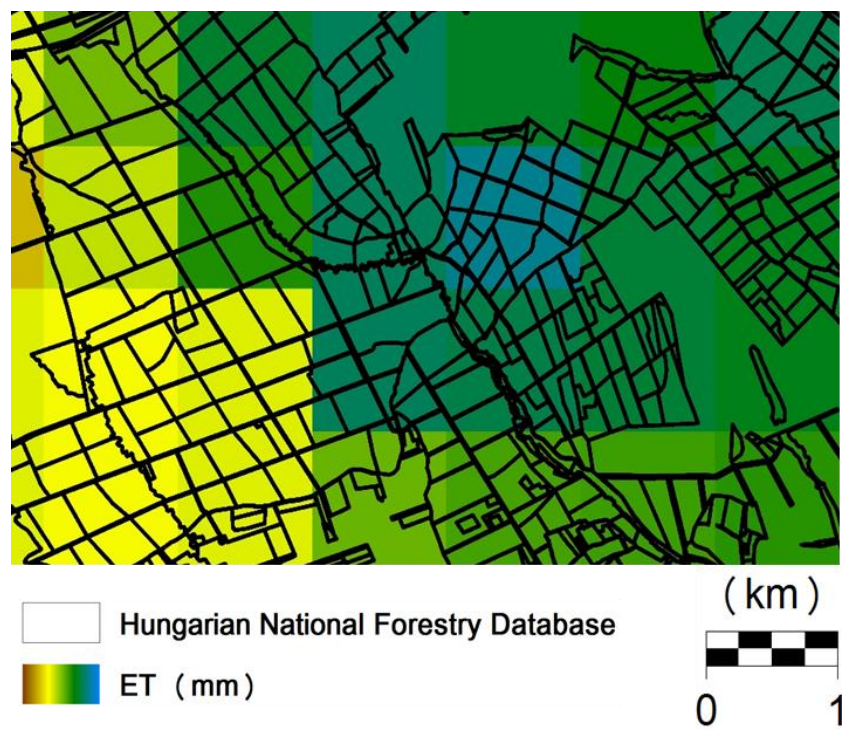

\section{MATERIALS AND METHODS}

Based on the literature review (Allen et al., 2011; Hong et al., 2011, Mahour et al., 2017), the MODIS normalized difference vegetation index (NDVI) data was selected as a co-variable for the CREMAP ET statistical downscaling. To download the NDVI data $(1000 \times 1000 \mathrm{~m}$ and $250 \times 250 \mathrm{~m}$ resolution), we used the Google Earth Engine platform (Gorelick et al., 2017). Two vegetation periods (Table 1) were selected for the 
examination: a drier and warmer one (May-Oct. 2003), and a wetter and colder one (May-Oct. 2005).

Table 1

The mean temperature (T) and the precipitation amounts (P) for the total years and for the vegetation periods of 2003 and 2005

\begin{tabular}{|c|l|c|c|}
\hline Year & \multicolumn{1}{|c|}{ Period } & T $\left({ }^{\circ} \mathbf{C}\right)$ & P (mm) \\
\hline \multirow{2}{*}{2003} & January - December & 10.8 & 467 \\
\cline { 2 - 4 } & May - October & 18.7 & 300 \\
\hline \multirow{2}{*}{2005} & January - December & 10.2 & 734 \\
\cline { 2 - 4 } & May-October & 17.4 & 445 \\
\hline
\end{tabular}

The water bodies and wetland areas were excluded, because they have a very low NDVI value in spite of their high ET. The correlation between the ET and the NDVI $(1000 \times 1000 \mathrm{~m})$ can be seen in Figure 2. The logarithmic regression fitted the best, thus, we calculated the ET values using the logarithmic equations and the NDVI $(250 \times 250 \mathrm{~m})$ data. In order to ensure that the mean of the downscaled 16 smaller ET pixels $(250 \times 250 \mathrm{~m})$ does not change within the original $1 \mathrm{~km}^{2}$ pixel, we used a quantization process.

Figure 2

\section{The NDVI and the evapotranspiration (ET): density plots and the regression equations}
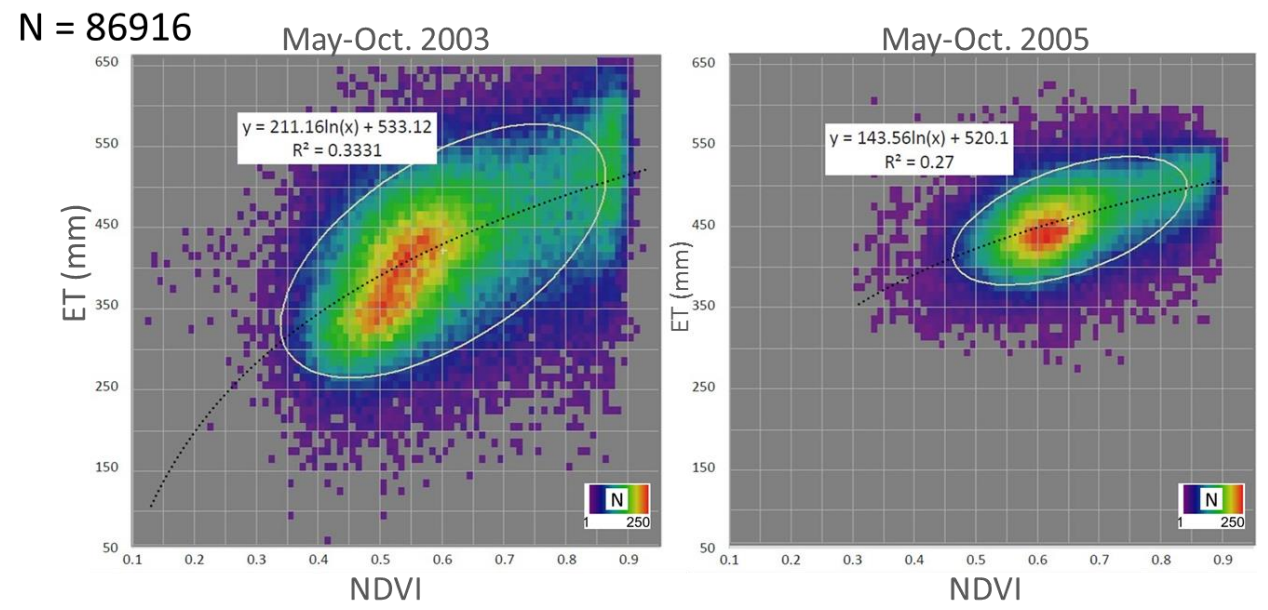

The ellipse contains $86.6 \%$ of data.

The Hungarian National Forestry Database was used to compare the ET of the following 15 forest stand types: "Beech", "Hornbeam-oak", "Sessile oak and 
pedunculate oak", “Turkey oak", "Pubescent oak", "Black locust”, “Other native hard broadleaves (hornbeam, maple, ash)", "Non-native hard broadleaves (red oak, black walnut, etc.)", "Hybrid poplar and willow", "Native poplar", "Other hygrophil species (willow, alder)", "Other native soft broadleaves (lime tree, birch, etc.)", "Scots pine", "Black pine", "Other pines (spruce, larch, etc.)". Only those ET pixels were included in the analysis which total area $(250 \times 250 \mathrm{~m}=6.25 \mathrm{ha})$ belonged to only one forest stand type ("homogeneous pixels").

\section{RESULTS}

The location of the filtered forest stands $(\mathrm{N}=10745)$ can be seen in Figure 3, while the ET of the different forest stand types is depicted in Figure 4.

\section{Figure 3}

The location of the filtered forest stands in Hungary

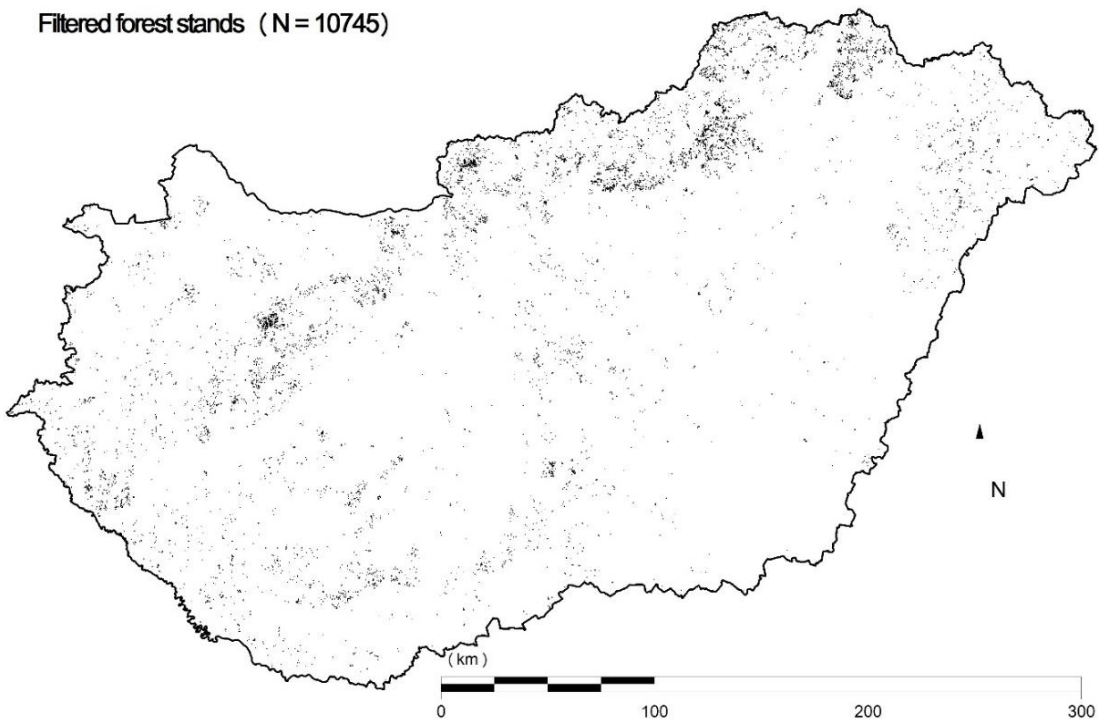

The differences between the ET of the different stand types were higher in the drier and warmer period (May-Oct. 2003). The spread of the values within each category was also higher in that period. In both periods the "Other hygrophil species (willow, alder)" category had the highest mean ET (571 and $535 \mathrm{~mm}$, respectively). It was followed by the "Beech" and the "Hornbeam-oak" categories. The lowest mean values belonged to "Black pine" in both periods (390 and $434 \mathrm{~mm}$, respectively). The "Pubescent oak", "Native poplar" and "Other pines (spruce, larch, etc.)" categories also had low mean ET values. The mean ET of the "Beech", "Hornbeam-oak" and "Other hygrophil species (willow, alder)" categories were higher in the drier and warmer year (2003) than in the wetter and colder years (2005). The "Pubescent oak", "Other native hard broadleaves (hornbeam, maple, ash)", "Non-native hard broadleaves (red oak, black walnut, etc.)", 
"Native poplar", "Other native soft broadleaves (lime tree, birch, etc.)"and "Black pine" categories had higher mean ET values in the second period (2005). The mean values of the other categories ("Sessile oak and pedunculate oak", "Turkey oak", "Black locust", "Hybrid poplar and willow", "Scots pine", "Other pines (spruce, larch, etc.)") were similar in both periods.

\section{Figure 4}

\section{Comparison of the evapotranspiration (ET) of different forest stand types.}

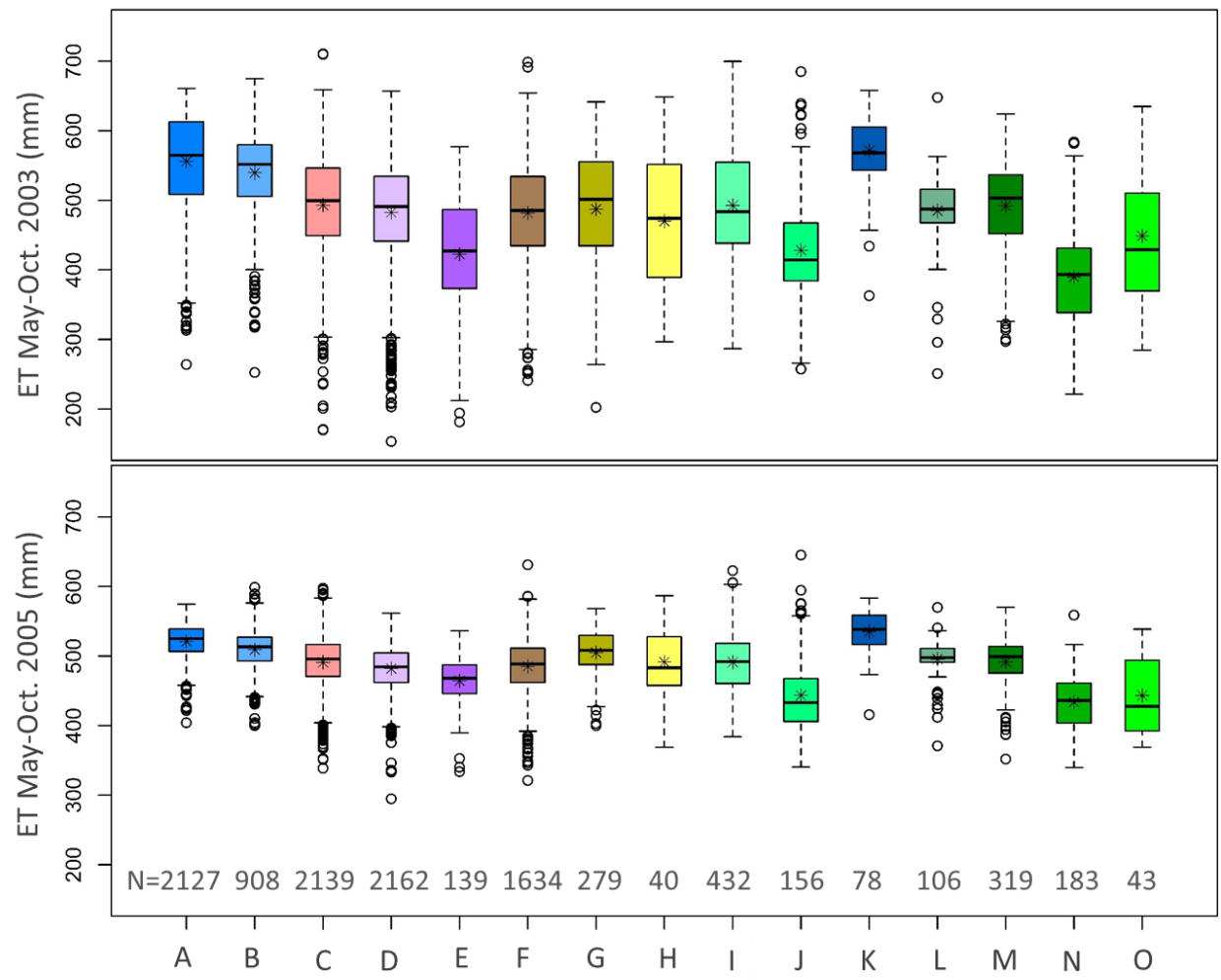

Forest stand types

A: "Beech", B: "Hornbeam-oak", C: "Sessile oak and pedunculate oak", D: "Turkey oak", E: "Pubescent oak", F: "Black locust", G: "Other native hard broadleaves (hornbeam, maple, ash)", H: "Non-native hard broadleaves (red oak, black walnut, etc.)", I: "Hybrid poplar and willow", J: "Native poplar", K: "Other hygrophil species (willow, alder)", L: "Other native soft broadleaves (lime tree, birch, etc.)", M: "Scots pine”, N: "Black pine”, O: "Otherpines (spruce, larch, etc.)".

\section{CONCLUSIONS}

The downscaled data obviously have more uncertainty than the original values (Hong et al., 2011). The main uncertainties of the downscaled products stem from the 
following sources: the uncertainties of the remote sensing based data - the MODIS surface temperature used for the original CREMAP ET values and the MODIS NDVI - (Miura et al., 2000; Sun et al., 2004), the uncertainties from the use of the regression equations, and the uncertainties of the Hungarian National Forestry Database (Bárdos, 2016). For water bodies and wetland areas the method cannot be used (very low NDVI in spite of high ET). The MODIS leaf area index (LAI) probably would have stronger correlation with ET, although it is currently available only with a resolution of $500 \times 500 \mathrm{~m}$.

Considering the uncertainties, the presented method can be used as a basis for statistical downscaling of remote-sensing based ET data for Hungary. With the downscaled products the ET of different forest stand types are comparable. In the future, more reliable remote sensing based data with higher spatial resolution may be available, which could help with the further improvement of statistical downscaling.

\section{ACKNOWLEDGEMENTS}

The publication of this paper is supported by the EFOP-3.6.2-16-2017-00018 "Produce together with the nature - agroforestry as a new outbreaking possibility" project.

\section{REFERENCES}

Allen, R.G., Pereira, L.S., Howell, T.A., Jensen, M.E. (2011): Evapotranspiration information reporting: I. Factors governing measurement accuracy. In: Agricultural Water Management, 98. 6. 899-920. p. doi: j.agwat.2010.12.015

Bárdos, Zs. (2016): Az erdők vízháztartásra gyakorolt hatásának értékelése párolgástérképek segítségével a Kiskunságban (In Hung.). MSc thesis. University of West Hungary, Faculty of forestry, Sopron.

Bouchet, R.J. (1963): Évapotranspiration réelle et potentielle signification climatique. In: International Association of Hydrological Sciences, 62. 134-142. p.

Gorelick, N., Hancher, M., Dixon, M., Ilyushchenko, S., Thau, D., Moore, R. (2017): Google Earth Engine: Planetary-scale geospatial analysis for everyone. In: Remote Sensing of Environment, 202. 18-27. p. doi: 10.1016/j.rse.2017.06.031

Hong, S.-H., Hendrickx, J.M.H., Borchers, B. (2011): Down-scaling of SEBAL derived evapotranspiration maps from MODIS $(250 \mathrm{~m})$ to Landsat $(30 \mathrm{~m})$ scales. In: International Journal of Remote Sensing, 32. 21. 6457-6477. p. doi: 10.1080/01431161.2010.512929

Mahour, M., Tolpekin, V., Stein, A., Sharifi, A. (2017): A comparison of two downscaling procedures to increase the spatial resolution of mapping actual evapotranspiration. In: ISPRS Journal of Photogrammetry and Remote Sensing, 126. 56-67. p. doi: 10.1016/j.isprsjprs.2017.02.004

Miura, T., Huete, A.R., Yoshioka, H. (2000): Evaluation of sensor calibration uncertainties on vegetation indices for MODIS. In: IEEE Transactions on Geoscience and Remote Sensing, 38. 3. 1399-1409. p. doi: 10.1109/36.843034 
Morton, F.I., Ricard, F., Fogarasi, S. (1985): Operational estimates of areal evapotranspiration and lake evaporation - Program WREVAP. In: NHRI Paper (National Hydrological Research Institute) 24.

Nouri, H., Beecham, S., Kazemi, F., Hassanli, A.M., Anderson, S. (2013): Remote sensing techniques for predicting evapotranspiration from mixed vegetated surfaces. In: Hydrology and Earth System Sciences Discussions, 10. 3. 38973925. p. doi: 10.5194/hessd-10-3897-2013

Sun, L., Chen, L.F., Liu, Q., Liu, Q.H., Song, A.B. (2004): Analysis on uncertainty in the MODIS retrieved land surface temperature using field measurements and high resolution images. In: IEEE International Geoscience and Remote Sensing Symposium, 2004. IGARSS '04. Proceedings. 3. 2083-2086. p. doi: 10.1109/igarss.2004.1370767

Szilágyi, J., Kovács, Á., (2011): A calibration-free evapotranspiration mapping technique for spatially-distributed regional-scale hydrologic modeling. In: Journal of Hydrology and Hydromechanics, 59. 2. 118-130. p. doi: 10.2478/v10098-011-0010-z

Zhang, K., Kimball, J.S., Running, S.W. (2016): A review of remote sensing based actual evapotranspiration estimation. In: Wiley Interdisciplinary Reviews: Water, 3. 6. 834-853. p. doi: $10.1002 /$ wat 2.1168

Corresponding author:

\section{Péter CSÁKI}

University of Sopron

Institute of Geomatics and Civil Engineering

H-9400 Sopron, Bajcsy-Zsilinszky 4.

Tel: + 3699 518-146

e-mail: csaki.peter@uni-sopron.hu 